\title{
LIMITATIONS ABROAD ON ENTERPRISE AND PROPERTY ACQUISITION
}

\author{
Dudley B. Bonsal* and Milo A. Borges $\dagger$
}

\section{INTRODUCTION}

We are only now emerging from the greatest international conflict in history. At the present writing no peace treaties have been signed. No one can guess with any degree of accuracy what effect those treaties may have on existing treaties and international agreements. Furthermore, it is not clear whether we are moving into a period of international cooperation based on the conception of the equality of states and freedom of peoples everywhere to trade with one another, or whether we will see a revival of the old balance of power theory with a division of the world into different camps having conflicting and competing trade policies and each led by one of the great powers.

In discussing the subject of this article, it must be borne in mind that today normal channels of trade are non-existent between the United States and many commercially important countries, and moreover that wartime restrictions on trade still survive even in countries which were not touched by the military operations of the war.

A natural aftermath of the war has been an increase of economic nationalism in many countries. Some of the greater powers seek in this way to rebuild and strengthen their economies to a point where they hope they will become invulnerable to military attack or to economic domination. Many smaller countries seek to attain greater bargaining power vis-à-vis the great powers and greater selfsufficiency in the event their trade relations with the great powers are cut off by another world conflict. Inevitably this economic nationalism breeds ever greater restrictions or limitations abroad on foreign enterprise and property acquisition and on the interchange of goods between countries.

While the United States is formally on record in favor of reducing trade barriers and the American Republics subscribed to liberal trade principles at the InterAmerican Conference on Problems of War and Peace held in Mexico City in

*A.B., I927, Dartmouth College; LL.B., I930, Harvard University. Member of the New York Bar; partner in the firm of Curtis, Mallet-Prevost, Colt \& Mosle; member of the New York State Bar Association and of the Association of the Bar of the City of New York. Chief Counsel, Office of InterAmerican Affairs (1942-r945). Member of the United States Delegation to the Inter-American Conference on Problems of War and Peace, Mexico City, 1945.

† LL.B., 1928, New York Law School. Member of the New York Bar; specialized in Latin-American law; partner in the firm of Curtis, Mallet-Prevost, Colt \& Mosle; member of the New York County Lawyers' Association (ex-chairman committee on foreign law). Author of a digest of Cuban Legislation 1895-1934 and supplements, and of a manual of Colombian Legislation 1931-1944. 
February and March of 1945 , no country, not even the United States, has as yet made any substantial progress toward achieving these aims. However, given time, the United Nations and its subsidiary organizations, the Paris Peace Conferences now in progress and proposed international trade conferences may usher in a new era in which the peoples of the world will recognize their own economic interdependence and in which international law as well as municipal law will give effect to that recognition. When that day arrives the trading nations of the world will have discarded their selfish aims in an effort to secure broader economic objectives, and we can expect the elimination of substantially all of the restrictions here discussed which interfere with sound international trade.

In the past the right of our citizens to trade and acquire property abroad has been recognized and protected through treaties of friendship, commerce and navigation. In recent years, reciprocal trade agreements and treaties for the prevention of international double taxation have been negotiated with a number of countries.

Under our treaties of friendship, commerce and navigation we have sought to obtain for American citizens freedom of trade, protection to their person and property, and most favored nation treatment. These treaties, of course, are reciprocal in nature and afford our people abroad no greater rights or protection than we are prepared to give at home to the people of the other signatory country. Thus, when our policy with respect to immigration changed from one of inviting immigration to one of restricting it, we began including in our treaties of commerce and friendship clauses to the effect that these treaties would not apply to immigration, and consequently, we find ourselves today in a position where American emigration to foreign countries could be restricted or forbidden without doing violence to the treaties.

Almost all of the existing friendship, commerce and navigation treaties are antiquated; some of them were entered into over one hundred years ago and many of them were signed at a time when modern concepts of trade and business organization were unknown. The pattern so established over one hundred years ago and which has been followed through the years does not appear adaptable any longer to present changing economic relations between countries. A new pattern must be created.

While few treaties for the prevention of double taxation have yet been signed, they constitute an important step forward in forestalling unreasonable tax barriers on international trade. ${ }^{1}$ The reciprocal trade agreements made by this country in recent years brought about a reduction of certain trade barriers by bilateral action, but unfortunately the outbreak of World War II interfered with the effectiveness of many of them.

The reciprocal trade treaty program, however, was a recognition of the inadequacy of the old style treaties of commerce, and a courageous admission on the

\footnotetext{
${ }^{1}$ The most important ones entered into so far, the ones with the United Kingdom, still await ratification at this writing.
} 
part of this country that we also had to make substantial concessions to other nations through the reduction of tariff barriers, if we expected to further our own export trade.

The next logical step would appear to be to bring about the reduction of trade barriers and restrictions through multilateral action, and this possibility is now being promoted by the Department of State. So we find that in November, I945, the Department of State issued a White Paper known as "Proposals for Expansion of World Trade and Employment" for consideration by the people and the governments of other countries and suggested that the Economic and Social Council of the United Nations call an international conference on trade and employment late this year to discuss international agreements relating to the achievement and maintenance of high and stable levels of employment and economic activity, restrictions and discriminations affecting international trade, restrictive business practices, intergovernmental commodity arrangements and the establishment of an international trade organization as a specialized agency of the United Nations.

These proposals afford a splendid opportunity to eliminate cumbersome and discriminatory trade restrictions and to bring about multilateral agreements which will guide international trade relations, provide universally accepted policies for the development of private international trade and establish general and sound commercial practices beneficial to the participating nations.

Unquestionably such an approach to the problem should prove more effective and satisfactory than the old bilateral agreements with their most favored nation clauses.

American foreign business interests acting individually and through nationally known business organizations are taking a keen interest in the success of the proposed conference.

The work of the Conference will undoubtedly be made more difficult by existing economic trends. Among other conflicting concepts is that between international trade carried on or controlled by states with that carried on by private enterprise. We in this country are dedicated to the principle that except in time of war, international trade and foreign enterprise should be left to private initiative. Generally speaking, all the European countries which were belligerents in the last war, have today more or less complete monopolies of foreign trade with the possible exception of Belgium and Holland. The United Kingdom in recent years has veered towards a system of international trade controlled by the state to the end that her imports shall be limited to those that the state deems essential, and shall balance her exports. The United Kingdom is in the process of nationalizing certain industries. The recent decision of the British Government to close permanently the Liverpool Cotton Futures Market and to replace it with a Central Government buying agency or commission has caused considerable criticism both in this country and abroad. It may well be true that this action should not be regarded as indicative of a settled policy in the United Kingdom toward governmental bulk buying but it is certain 
to be viewed in many quarters as a distinct step away from the re-establishment of private enterprise in the field of foreign trade. Poland and Czechoslovakia have recently taken steps towards the nationalization of a number of industries. China, in the throes of reconstruction, may go the same way. Yugoslavia has taken over all public utility and petroleum properties formerly owned by American interests. All these are symptomatic of a trend which if unchecked will result in our problem being not one of foreign restrictions on our enterprise and property acquisition abroad, but one of complete control.

To meet this peril it is important that we prove to the world that we are sincere in our purpose to eliminate trade barriers for the common good, and not solely with a view to fostering our own export trade. In the past our government as well as private business has thought too much in terms of exports and has gauged the success of our foreign commerce by the size of our favorable balance of trade. We should become import minded as well as export minded. We must allay the suspicion which still lingers abroad that our aims are selfish, and which has been recently described by the eminent French writer Andre Siegfried in the following terms:

"The powerful are feared and, inevitably, also envied. Having, herself, a long record of conquests and imperialisms, Europe is quick to attribute to America ambitions and ulterior motives which would be characteristic of this older continent if it were today in the position of America. Europeans therefore suspect the United States is determined to acquire control of a whole system of naval and air bases stretching across oceans and continents and to bring pressure everywhere to reduce other people's tariffs for the benefit of Americans, without necessarily intending to reduce the American tariff. The highly vocal American criticism of colonial empires is explained by remarking that the United States has no need of colonies.

"This attitude springs from skepticism and from more than a trace of fear, with which is mingled the resentment of a continent that has now been deprived of its ancient hegemony in the world."2

Our own actions in allaying this suspicion will bring about a greater readiness on the part of other countries to work with us towards the solution of trade problems by multilateral negotiations and agreement.

Until the results of the proposed World Trade and Employment Conference are known, and until peace treaties and definite post-war trade policies are established, it is impossible to write an article which will serve as a world-wide guide to lawyers advising clients on particular restrictions on foreign trade.

The most that can be done today is to indicate some of the present restrictions which find more or less general application in those areas of the world where there is today something approaching normal conditions of trade.

In discussing various limitations on enterprise and property acquisition, it must be remembered that all of them are not necessarily unjustified or unreasonable.

${ }^{2}$ Siegfried, They Envy Us, They Fear Us (April 2I, 1946) New YorK Times MaG. 
Some of them differ only slightly from those imposed by certain of our states. ${ }^{3}$ The unreasonableness may arise from the extent to which the restriction is carried. If Cuba chooses to restrict the practice of a profession to Cuban citizens by birth or naturalization, she should not be criticized for doing so, but where this Cuban restriction goes so far as to provide that a naturalized citizen cannot practice a profession requiring licensing until after five years have elapsed since his naturalization that restriction would seem unduly harsh. ${ }^{4}$

The growth of economic nationalism breeds with it ever more burdensome barriers on international trade. However, it would be a mistake to assume that all limitations on foreign enterprise and foreign property acquisition stem from this cause. Many of the limitations here discussed stem from a very natural and proper desire on the part of a people to share in the benefits resulting from the exploitation of their natural wealth and the economic development of their countries. No selfrespecting people could be expected to stand quietly by while foreign capital, management and labor exploit their resources and take with them all of the fruits of the enterprise. Our Latin-American neighbors saw too much of this in the days of the Spanish Empire and after they became independent nations. Many of the restrictions here reviewed stem from this very natural and understandable attitude.

The reader will appreciate that the countries of Europe, Asia and Africa are for the most part still going through the transition from war to peace, and in many of them ordinary constitutional and legal processes are still suspended or in the course of revision or reorientation. ${ }^{5}$ Therefore, any article written today must be largely confined to the limitations and restrictions which have prevailed and continue in force in the countries of this hemisphere.

\section{Subsoll aNd LAND OWNERship}

Most countries recognize the right of foreigners to own real estate and interests in the subsoil. A number of them guarantee the rights of foreigners in this connection either in their constitutions or by statute. Argentina and Brazil, for example, each have constitutional provisions giving foreigners equal rights with na-

\footnotetext{
${ }^{3}$ A number of our states, including Arizona, Arkansas, California, Idaho, Kansas, New Mexico and Wyoming prohibit the ownership of land by aliens not eligible for citizenship, these statutes being primarily directed against the Japanese. Illinois has a statutory, provision that an alien cannot hold real estate for more than six years. Indiana limits all holdings of real cstate by aliens to 320 acres and the land so held escheats to the state if the owner does not become a citizen or convey the land within a period of five years. Iowa likewise limits aliens to 320 acres, while Minnesota's limitation is 90,000 square feet. Mississippi does not permit non-resident aliens to acquire land except as security for a debt or as a result of a purchase at a judicial sale where their tenure is limited to twenty years. Norrresident aliens are likewise excluded from holding real estate in Oklahoma except that they may take by devise in which event they can hold for five years.

In addition many states have restrictions on the type of activity in which aliens may engagc. Most of these apply to professions although New Hampshire and some other states deny to aliens the right to own pistols.

- Cuba: Constitution of r940, Art. 82.

5 The situation in Western Europe and the Far East was summarized in the carly part of the current year by Mr. Henry Chalmers of the Department of Commerce in Chalmers, Major Trade-Policy Trends During 1945 (Feb. 9, r946) Foreign CoMmerce WeekLy 3.
} 
tionals of those countries. ${ }^{6}$ Brazil, however, nothwithstanding the above-mentioned constitutional provision, has imposed limitations on the rights of foreigners to hold land and rights in the subsoil. By statute there are limitations on the rights of foreigners with respect to land situated near the national frontiers ${ }^{\top}$ and Article 143 of the 1937 Constitution restricts the exploitation of mines, mineral deposits or any other subsoil wealth and hydroelectric power to Brazilians or to companies entirely composed of Brazilians.

With respect to the ownership of land, the limitation most generally found is one arising from the needs of national defense. These restrictions apply usually to strategic parts of the country including land lying near an international frontier or near the seaboard. These areas are commonly referred to in Latin America as prohibited zones. Sometimes the prohibition is absolute. Mexico, for instance, has a prohibited zone consisting of a strip of roo kilometers in width along its international frontiers and 50 kilometers in width along its coastline. Foreigners are prohibited from owning land or water rights in this zone. ${ }^{8}$

Ecuador has a prohibited zone running 50 kilometers in width along its frontiers and along its coastlines and in this zone foreigners are forbidden to acquire rural property either directly or indirectly through individual ownership or through corporations. ${ }^{9}$ Any acquisition by foreigners contrary to the Ecuadorian law may be declared null and void.

Peru also has a prohibited zone of 50 kilometers in width along its frontiers in which foreigners are forbidden to have any interest in land, water rights or mines under penalty of forfeiture to the state. In Peru lands and buildings located near military establishments are included in the prohibited zone. However, Peru provides for exceptions if covered by special laws. ${ }^{10}$

In Brazil the prohibited zone is a strip 150 kilometers wide along its frontiers. This prohibition is not absolute being applicable only to land holdings in excess of 2,000 hectares. ${ }^{11}$

Haiti has no prohibited zone but foreigners and foreign corporations can acquire real property in that country only if they are residents thereof and then only for limited purposes, such as residence, farming, manufacturing or education. Foreigners lose their right to hold real estate in Haiti one year after they cease to be residents of that country, or, in the case of a company, one year after it ceases doing business there. In such event, the lands so owned may be sold under government direction and the proceeds of sale paid over to the owners. ${ }^{12}$

Mexico limits the right of foreigners or foreign companies or Mexican companies

'Argentina: Constitution of $x 853$, art. 20, as amended; Brazil: Constitution of $x 937$, art. r22.

"Brazil: Decree-Law 6430 of April 17, 1944: Coleçẫo das LeIS de 1944, Vol. III, p. 30.

Mexico: Constitution of I9r7, art. 27 , sec. I.

- Ecuador: Decree of Oct. 3, 1940: Registro Ofictal No. 35 of Oct. 14, 1940.

${ }^{10}$ Peru: Constitution of 1920 , art. 39; Decree of July 22, 194I, EL Peruano No. 170 of July 24, $194 x$.

11 Brazil: Decree-Law 6430 of April 17, I944: Coleção das LeIs de 1944, Vol. III, p. 30.

${ }^{12}$ Haiti: Constitution of 1944 , art. 8. 
having foreign stockholders, to own land in parts of the country lying outside the prohibited zone. The acquisition of such lands is dependent on obtaining a license from the Ministry of Foreign Affairs. It is a condition of any license that the applicants shall consider themselves Mexican for the purpose of the proposed acquisition and ownership of land and shall renounce the protection of their home government. Moreover, the Ministry of Foreign Affairs may require that more than $5^{\circ}$ percent of any corporation acquiring such lands shall be owned by Mexicans and that a majority of the Board of Directors of any such corporation shall be Mexican. ${ }^{13}$ With respect to farm lands the license application must be denied if 50 percent or more of the ownership would be in foreign hands. ${ }^{14}$ Finland formerly required foreigners to obtain government permission before acquiring land in that country, or before leasing land for a term of more than five years. ${ }^{\mathbf{1 6}}$ We do not know whether this restriction has continued in force after the war.

Norway and Sweden ${ }^{16}$ likewise requires foreigners to obtain government permission to purchase or hold real estate or to engage in mining operations.

As regards rights in the subsoil, we have already referred to the prohibition contained in the Brazilian Constitution of 1937 which excludes foreigners from the privilege of owning subsoil rights. This prohibition extends to Brazilian companies with foreign stockholders.

Following the expropriation of the foreign oil properties in Mexico, that country by decree determined that the exploitation of oil belonged exclusively to the nation. Since that decree, which was enacted on December 27, 1939, no foreigner may own petroleum properties or engage in the production of petroleum in Mexico. ${ }^{17}$ In Venezuela and in most other Latin-American countries rights in the subsoil are the property of the nation. This is also true of Colombia unless the original private title was acquired prior to 1873 .

The fact that a certain country does not restrict the ownership of land and subsoil rights by foreigners does not necessarily imply that the foreigners may exploit the substances of the subsoil without government authorization. There are countries where not only the foreigners but nationals as well must obtain a license or concession to be able to operate a mine. Even the exploitation of forests either by foreigners or nationals may in some countries require a permit or license.

On the other hand in Colombia and Venezuela where the rights in the subsoil are reserved to the nation, a foreigner or foreign corporation may obtain a concession from the government to exploit the subsoil.

${ }^{13}$ Mexico: Constitution of 1917 , art. 27 , secs. I and IV, and regulations thercof contained in:

1. Organic Law of Dec. 3I, 1925, arts, I, 2, 3, 4, Diario Oficial of Jan. 2I, 1926.

2. Decree of June 29, x944: Diario Oficial of July 7, I944 ratified by Act of Congress of Sept. 28, I945, Diario Oficial of Oct. I, I945.

${ }_{14}$ Mexico: Organic Law of Dec. 31, 1925, art. 3: Diario Oficial of Jan. 21, 1926.

${ }^{15}$ Finland: Statutes of 1939, No. 219.

10 Law of May 30, 1916.

${ }^{17}$ Mexico: Decree of Dec. 27, 1939: Diario Oficial of Nov. 9, r940. 
In Colombia, foreign companies engaged in the exploitation of petroleum must become domiciled in Colombia and these companies are considered Colombian for all purposes. ${ }^{18}$

\section{Labor Laws}

In setting up new enterprises in foreign countries it is extremely important to give careful study to the labor laws of the country involved. There are numerous laws to be considered relating to method of employment, term of contract, regulations affecting termination of employment, old age pensions, workmen's compensation, etc. For the purposes of this article, however, it will be sufficient to dwell on that body of law which requires the employment of nationals of the country in which the industry is located. These requirements stem from the public policy of many countries to give maximum employment to their citizens and to afford them the opportunity to learn modern techniques brought in from the outside to the end that eventually the need for foreign technicians and managerial skill will be largely eliminated. While these restrictions may cause a hardship in particular cases where the enterprise requires substantial numbers of highly skilled employees, by and large they have not been considered a serious obstacle to American enterprise in foreign countries, with the exception of Cuba, to which we now refer.

The law nationalizing labor in Cuba, which is known as the $5^{\circ}$ percent law, provided that upon its enactment in $19335^{\circ}$ percent of all labor then employed in any one enterprise must be Cuban and that all replacements must be of Cuban nationality until eventually too percent of the workers would be Cuban. ${ }^{19}$ Any new enterprise is required to employ roo percent Cuban labor except that if a Cuban skilled technician of the type needed is unavailable, a foreign technician may be employed if authorization is obtained from the Ministry of Labor. Pursuant to the law of nationalization of labor, the Cuban Minister of Labor has issued several resolutions on this subject, the latest of which sets forth the requirements to be complied with before a foreign technician can be employed. According to this resolution ${ }^{20}$ in order to employ a foreign technician it is necessary for the employer to file a petition with a Labor Office giving the name of the technician, a description of the technical work he is to perform, the efforts made unsuccessfully to find a Cuban qualified to do the work, the compensation to be paid to the technician, the name of the Cuban apprentice to be employed to replace the foreign technician upon conclusion of his apprenticeship, and other details. Proof must be furnished that a notice has been published in the local newspapers advertising the need of such technician and calling for Cuban applicants. The petition is referred to an official labor employment office and eventually reaches the Minister of Labor. If the petition is granted the employment of the foreign technician is authorized for a

${ }^{18}$ Colombia: Petroleum Law No. 37 of 193 I: Diano Oficiat. No. 21637 of March ro, r93x, p. 489.

${ }^{10}$ Cuba: Law Nationalizing Labor, Decree 2583 of Nov. 8, 1933: Gaceta Oficial of Nov. 8, 1933, p. $6 \mathrm{r} 45$.

${ }^{20}$ Cuba: Resolution No. 868 of April 10, 1945: Gaceta Ofrciat of April 24, 1945, p. 8ro4. 
limited period of time, not to exceed one year. If in the meantime the apprentice qualifies for the work or if a qualified Cuban becomes available, the foreign technician must be discharged. The foreign technician cannot be employed while the petition is pending.

Less stringent laws are found in the other American Republics.

In Mexico 90 percent of the technical workers and 90 percent of the unskilled labor in any particular enterprise must be Mexican, except that if there are five or less employees the percentage is reduced to 8o. Mexico permits the employment of foreign technicians only where Mexicans possessing the necessary skill are not available, and requires the training of Mexican technicians to take the place of foreign technicians as soon as they are able to do so. ${ }^{21}$

Bolivia requires that 85 percent of the employees be Bolivian and 85 percent of the payroll must go to Bolivians except in certain special cases. ${ }^{22}$

Colombia provides that not more than ro percent of laborers nor more than 20 percent of the clerical employees may be aliens and not more than 20 percent of the laborers' payroll and 30 percent of the payroll of other employees may go to aliens. ${ }^{23}$

In Guatemala 75 percent of the employees must be Guatemalans, ${ }^{2-4}$ while in the Dominican Republic the percentage is 70 percent and in that country at least 70 percent of the payroll must go to Dominicans, with certain exceptions. ${ }^{25}$

In Brazil two-thirds of the employees must be Brazilians or foreigners who have resided in the country for at least ten years and who have a Brazilian wife or child. $^{26}$

The present requirement in Egypt calls for at least 50 percent of the clerical staff and 90 percent of the workmen being Egyptian. There is presently under consideration a proposal to increase the percentage of the clerical staff which must be Egyptian from $5^{\circ}$ to 75 .

Attention should be called in passing to the fact that there exist in some countries constitutional or statutory provisions based on the concept that equal work calls for equal pay. In these countries, therefore, employees who are nationals are entitled to the same pay as the foreign employees if they perform the same work. Cuba on the one hand, by its Constitution makes this an unqualified requirement. ${ }^{27}$

\footnotetext{
${ }^{22}$ Mexico: Federal Labor Law, art. 9, of Aug. I8, I93I, as amended: Diario Oricial of Aug. 27, r93r.

${ }^{22}$ Bolivia: Decreto Supremo of Feb. 2, I937: LegisLación Vigente, Vol. II (Dec., 1936-July, 1937), p. II4.

${ }^{23}$ Colombia: Law of Oct. 1, 1936: Diario Oficial No. 23342 of Nov. 24, 1936, and Decree of Aug. 6, 1937: Diarto Oficial No. 23590 of Sept. 25, 1937.

24 Guatemala: Decree No. 60 of ig45: Diario de Centro AmErica of Feb. 8, 1945.

25 Dominican Republic: Law 51 of i938: Gaceta Oficiat No. 5258 of Dec. 28, 1938.

${ }^{26}$ Brazil: Decree-Law No. 1843 of Dec. 7, 1939: Coleção das Lets de 1939, Vol. VIII, p. 299.

${ }^{27}$ Cuba: Constitution of 1940, art. 62 .
} 
Colombia, on the other hand, by statute ${ }^{28}$ recognizes and allows differences in pay based on professional or technical ability, seniority, experience, family obligations or labor efficiency.

While the laws limiting the employment of aliens are often absolute by their terms, if the foreign enterprise is deemed desirable, and the need for foreign personnel is justified, usually a way will be found to permit the employment of the necessary foreign personnel.

\section{Some Practical Questions about Business Restrictions .}

Perhaps the most practical way to bring out the various restrictions and limitations that affect particular kinds of enterprises abroad is to put ourselves in the position of a United States individual or corporation contemplating doing business in another country.

The first question is to ascertain the country where the individual or corporation wishes to carry on his or its business. This is important because countries differ with respect to kinds of business which may be carried on by foreigners and in their requirements for admission of foreign businessmen or corporations.

The second question is the nature of the business. Certain types of businesses are subject to more restrictions or limitations than others, and in fact, some businesses are not permitted at all. Generally speaking, where the proposed business is in the field of aviation, shipping, mining, oil, radio broadcasting or telecommunications, or where the business will compete with already established local enterprises receiving special protection from the foreign country, or where the particular line of business is either one which is reserved by the foreign country for development by its own citizens or a type of business which is too closely related with the cultural and traditional way of life of the foreign country, the new enterprise probably will be faced with restrictions, limitations and even prohibitions. There are, however, many lines of endeavor in the industrial field, where admission is readily obtained and if the industry is new and deemed important to the economic development of the country, it may be encouraged by concessions in the form of tax reductions or exemptions from duties.

The third point is to determine the method of operation.

\section{Factors in Choice of Country}

With regard to the selection of the particular country by an individual, it will first be necessary to ascertain the requirements and limitations of the foreign country in which he intends to establish his residence and engage in business. These requirements are usually found in constitutional and statutory provisions, but the general immigration policy of the country must be considered. The statutory provisions may disclose quota limitations or certain prohibitions relating to undesirable aliens, and in some cases the necessity of making a cash deposit. Some countries limit the activities of aliens who engage in commercial enterprises. In Mexico the entry of aliens even as visitors for business purposes requires authorization by the

${ }^{28}$ Colombia: Law 6 of 1945: Diario Oejcial No. 25790 of March 14, 1945, p. 953. 
immigration authorities which may be rejected or granted in their discretion and if granted it may be subject to certain prescribed conditions. ${ }^{29}$ In some instances, as in the case of Brazil, the visa of the Brazilian Consular officer is not granted under present regulations without first obtaining approval by the Brazilian Foreign Office for which purpose the nature of the business in which the applicant is to engage must be disclosed, together with other pertinent information, to enable the Brazilian Foreign Office to decide whether or not the admission of the immigrant will be granted.

Through these proceedings and by applying the provisions usually found in the various immigration laws requiring assurance that the immigrant will not become a public charge, the foreign country is able to select the type of immigration it desires, and to exercise certain controls over the type of business in which the immigrant may engage. The tendency has been in recent years to discourage immigration and to allow admission only to those foreigners who through their special training and qualifications may be helpful in developing new industries or in becoming desirable citizens, according to the standards of the particular country.

Without listing all the requirements for entry into a foreign country, it should be mentioned that in some countries like Colombia an immigrant must make a cash deposit which will be returned to him if he leaves the country or shows after a five-year period of residence in the country that he has established a permanent business, with a minimum capital of 5,000 pesos. ${ }^{30}$ An immigrant seeking to invest money in Mexico is required to prove that he has a minimum capital of ro0,000 pesos or approximately $\$ 20,000$ if he intends to do business in the Federal District, or 20,000 pesos if he intends to do business in any municipality or state capital and 5,000 pesos if he intends to do business in any other part of the country. ${ }^{31}$ An individual going abroad will find that in some countries he is not allowed to engage in certain businesses, professions or occupations, and we shall discuss this matter when we take up the question of the nature of the business.

France $^{32}$ and Belgium ${ }^{33}$ prescribe certain conditions which must be met before foreigners can engage in business in those countries. In brief they are required to obtain and carry with them a commercial card which sets forth the type of business they are authorized to transact.

The United Kingdom also has requirements limiting the right of foreigners to engage in business. As a practical matter these requirements do not restrict the activities of a foreigner who is bringing capital into the country and whose enterprise will give employment to British subjects.

If an American corporation opens a branch or engages in business in a foreign country, the general rule is that it must qualify or register in that country. The

\footnotetext{
${ }^{30}$ Mexico: General Law of Population, arts. 75, 76, 79: Diario Oficial of Aug. 29, 1936.

${ }^{80}$ Colombia: Decree 397 of Feb. 17, 1937, as amended: Diario Oficial No. 23455 of April 15, 1937.

${ }^{21}$ Mexico: General Law of Population, art. 88, sec. I: Diario Oficind of Aug. 29, 1936.

s" France: Decree of Nov. 12, 1938.

3s Belgium: Royal Decree of Nov. 16, 1939.
} 
registration of a foreign corporation may be accomplished either through executive authorization or administrative registration. In Brazil the registration must be authorized by a decree signed by the President. ${ }^{34}$ In Colombia, after complying with all requirements for administrative registration, the Superintendent of Corporations must be satisfied that the legal requirements have been complied with before he will issue a license to operate. ${ }^{35}$ In the Argentine the corporation either applies for Presidential executive authorization or for approval of the documents by a Court of Commerce. ${ }^{36}$ If the former procedure is followed, the corporation will be subject to the discretionary powers of the President which may be exercised restrictively. If the latter procedure is followed the corporation must prove that the statutes of the jurisdiction where it is incorporated grant reciprocal rights to Argentine corporations. In Mexico registration can be obtained only on authorization from the Department of National Economy. ${ }^{37}$ Brazil requires that foreign corporations wishing to engage in business in that country declare and deposit in Brazil the amount of capital to be devoted to Brazilian operations which must be adequate for that purpose. ${ }^{38}$ In general, where executive authorization is required, broad latitude exists to grant or withhold or to impose conditions with respect to the admission of the corporation. This power is sometimes used to restrict the kinds of businesses in which foreigners may engage. In Mexico, particularly, the laws and regulations regarding licensing are so written as to give wide discretion to the authorities to exclude or limit foreign participation in enterprises which the authorities may deem should be restricted to or shared by Mexican nationals. ${ }^{39}$ In China a foreign corporation cannot qualify unless it transacts business in the country of its origin. In Bolivia, a foreign corporation engaging in mining operations must be domiciled and have a directorate in that country separate and apart from the Board of Directors it may have in the country of its origin. ${ }^{40}$

We shall not enter into a detailed statement of the documents which must be filed nor the steps which must be taken to accomplish registration, but it is suffciently important to say that an American corporation qualifying abroad must give a power of attorney to its representative giving him broad powers to act for and commit the corporation. This power of attorney is usually a formidable document.

In the majority of the countries where no executive authorization is required and qualification is obtained through mere administrative procedure, any foreign corporation can easily qualify and register to do business therein, provided the business is not one against the public policy of the country.

34 Brazil: Decree-Law No. 2627, art. 64, of Oct. 26, 1940: Coleção das Leis dE 1940, Vol. V, p. 353.

${ }^{35}$ Colombia: Decree No. 65 of 1941 : Diario Oficial No. 24567 of Jan. 21, 1941, p. 210.

${ }^{30}$ Argentina: Law No. 8867 of Jan. 30, I9I2: Leyes Nacionales, Vol. XVII, p. 542.

${ }^{37}$ Mexico: General Law of Mercantile Companies, art. 251 of Juy 28, 1934: Diario Oficial of Aug. 4, 1934 .

${ }_{38}$ Brazil: Decree-Law No. 2627, art. 65, of Oct. 26, 1940: Coleção das Leis de I940, Vol. V, p. 353.

${ }^{30}$ Mexico: Organic Law of Dec. 3r, I925, arts. 2, 3, 4, 6 and 8: Diario Oficial of Jan. 21, r926. Regulations of that Organic Law issued March 29, 1936; and Decree of June' 29, 1944, arts. I-4: Diario Opicial of July 7, I944, ratified by Act of Congress of Sept. 28, 1945: Diario Oficial of Oct. 1, 1945.

${ }^{10}$ Bolivia: Mining Code, sec. 137 as amended by Law of Feb. 23, 1927. 
Before leaving this topic we ought to call attention to the fact that the necessity of qualifying or registering to do business abroad depends on whether or not the corporation is doing business therein as this expression is legally understood, and that the legislation of some countries is liberal in this respect. In the Argentine a foreign corporation wishing to acquire real estate, to obtain a concession from the government or to render a public service must qualify, but a corporation engaging in commercial operations need qualify only in order to have the right to sue and to be able to obtain and keep an official set of books admissible in evidence in case of litigation. A foreign corporation may engage in a number of operations in the Argentine without registering, provided it maintains there a registered agent with proper authority to act for the corporation.

In Cuba the Supreme Court held in $1910^{41}$ that a foreign corporation holding title to mining properties and lands in Cuba, was not required to qualify or to be registered there. However, recently the authorities have interpreted the law providing for the registration of corporations ${ }^{42}$ in the sense that such a corporation must be registered.

The general question of what constitutes doing business is one which must be examined in each particular instance with reference to the laws of the particular country.

\section{Restrictions Depending on Kind of Business}

We now come to a discussion of the restrictions which may be imposed by reason of the nature of the business to be transacted. In the United Kingdom, for example, no foreigner may own an interest in a ship of British registry. ${ }^{43}$ In most maritime nations, coastwise service is reserved for nationals or national corporations. In some countries, a tendency is developing to require participation in local air lines by nationals and in Colombia this participation must be at least $5^{\text {I }}$ percent. ${ }^{44}$ In Brazil no foreign individual or foreign corporation and no Brazilian corporation having foreign stockholders may engage in the oil business. ${ }^{45}$ The same holds true for Mexico. ${ }^{46}$ In Honduras an alien may not be a radio operator ${ }^{47}$ while in Colombia an alien may not operate a broadcasting station. ${ }^{48} \mathrm{We}$ find that in Panama only Panamanians by birth or naturalization and aliens married to Panamanians or who have children born in Panama may engage in retail trade. ${ }^{40}$

${ }^{21}$ Cuba: Decision No. 8 of April 19, igro: Jurisprudencia dec Tribunal Supremo en Materia Civil DE I9I0, p. I26.

\$2 Cuba: Decree-Law No. 842, art. 3, of April 20, 1936: Gaceta Oficial, Edición Extraordinaria No. 136 of April $3^{\circ}, 1936$.

${ }^{43}$ Merchant Shipping Act, 1894, 57-58 VIcr. c. 60.

* Colombia: Law 89 of 1938: Diario Oficial No. 23789 of May 30, 1938.

${ }^{45}$ Brazil: Decree-Law No. 395 of April 29, I938: Coleçäo das LeIs de 1938, Vol. II (Decretos-Lcis), p. 72.

"Mexico: Decree of Dec. 27, 1939; Diakio Oficial of Nov. 9, 1940; New Petroleum Law of May 2, 1941: Diario Oficial of June 18 , 1941 .

"77 Honduras: Decree 573 of May 4, 1933: LA GACETA No. 8997 of May 15, 1933.

${ }^{48}$ Colombia: Law 198 of I936: Diario Oficial No. 23388 of Jan. 21, 1937.

40 Panama: Constitution of March 3, 1946, art. 234. 
In Mexico it has been fairly well established that corporations engaged in the production or distribution of motion pictures must be owned or at least controlled by Mexican citizens. It should also be remembered that many countries have monopolies with respect to such businesses as liquor, tobacco, matches, etc., and that in countries where such monopolies exist neither foreigners nor citizens of the country may engage in the business unless they obtain specific authority, in those countries where such authority is obtainable.

Limitations are also found in the insurance field. A number of countries, such as Mexico, require that insurance be taken out with Mexican companies or foreign countries which are authorized to carry on an insurance business in Mexico. ${ }^{50}$ It is now very difficult for a foreign company to secure such authorization. The trend in many countries to nationalize railroads and public utilities may in given instances operate as a restriction on foreigners who desire to engage in these activities.

The carrying on of certain professions, such as medicine, law and engineering is restricted in some countries to citizens by birth or naturalization and as we have previously stated, Cuba goes so far as not to permit the practice of certain professions to naturalized citizens until after five years from the date of naturalization.

With the exception of a few specific restrictions, some of which have been above referred to, foreign countries in which normal conditions prevail are liberal in permitting business enterprise to be carried on by foreign individuals and corporations. While businessmen at times deem it impossible to operate in a foreign country, this is usually due to exchange control and fiscal legislation rather than to any restriction on the type of business.

\section{Choice of Methods of Operation and Organization}

We shall now consider the third question above mentioned, viz., the method of operation. An American individual may decide that he will personally establish the business in the country and operate it himself, or he may wish to carry on the business through an agent who will be a resident of the country. If he is in the manufacturing or wholesale business in the United States, he may wish to carry on his business in the other country through the use of traveling representatives. If the proposed business activity involves the operation of a factory in the foreign country or the exploitation of mines or mineral resources, the American citizen or company will doubtless wish to carry on the enterprise through some type of business organization. If it is a small enterprise, he may choose to conduct the business through a partnership with other American or foreign associates. If an American company is concerned, that company may decide to qualify to do business in the foreign country or to form a separate company for the purpose. This other company may be either an American corporation or a business organization formed under the laws of the country involved. In some cases the enterprise in the foreign country may be completely owned by the American interests while in others the

\footnotetext{
${ }^{10}$ Mexico: General Law of Insurance Companies of Aug. 26, 1935: Diarro Oficial of Aug. 31, 1935.
} 
American interests may find it advantageous to associate themselves with local interests. We shall now consider each of these possible methods of carrying on the foreign enterprise and indicate some of the restrictions, limitations or difficulties that may be encountered.

We already have indicated the restrictions which may affect an individual American citizen who wishes to establish himself in business in a foreign country. The other aspects which must be considered in connection with the method of operation apply equally to citizens and corporations.

Resident Agents. One possible method is the employment of a resident agent in the country where it is proposed to carry on the business. If this method is used, the limitations or restrictions which may be encountered depend on the functions of the resident agent. If he maintains an inventory or has authority to accept orders it will be found in most countries that the American individual or concern is in effect doing business in the country and may be subjected to all of the rules and regulations imposed on foreigners or foreign corporations so engaged. However, if the resident agent's function is confined to the solicitation of orders for the sale of goods to be accepted and filled in the United States or to the role of a purchasing agent for the American citizen or American corporation, such requirements are usually inapplicable. In many cases the resident agent may not be an agent at all but an independent contractor, distributor, or commission merchant. Many American concerns sell abroad through established distributors who take delivery of the goods and resell them in their territory. This method usually presents no problem to the American individual or corporation other than the selection of a proper local distributor who is qualified under the laws of the country to act as such.

Traveling Salesmen. Where the American individual or corporation is engaged in the manufacturing or wholesale business in the United States, the activity in the foreign country may be confined to selling the products through the medium of commercial representatives or traveling salesmen who go out from the head office in the United States to the territory to be covered. In the nature of things these commercial representatives or traveling salesmen have a peculiar status in the countries in which they operate. They are not analogous to tourists or temporary visitors because the purpose of their visit is commercial. On the other hand they are not analogous to permanent residents since they do not intend to carry on business permanently in any particular country. in general, traveling salesmen encounter greater restrictions than do tourists, but are not subjected to as many restrictions as are encountered by immigrants or permanent residents.

Following World War I, American traveling salesmen in many countries found themselves faced with a number of practical difficulties in carrying out their functions. Besides the usual problem of obtaining visas for entry into the countries which they planned to visit, they were subjected upon arrival to many technical and sometimes exasperating regulations. There was the problem of customs duties 
on their samples and question might even be raised as to whether the samples would be admitted at all. Once these matters were taken care of, there arose problems with respect to obtaining licenses to carry on their business from numerous municipal authorities, imposition of taxes, etc.

The State Department took cognizance of the difficulties encountered by our traveling salesmen and beginning in I9Ig negotiated a number of conventions with other countries concerning traveling salesmen. In general these conventions provide that traveling salesmen may obtain a single license upon the payment of one fee, which license enables them to carry on their business throughout the country unmolested by local license requirements. They also provide for the simplification of customs requirements and where the salesmen's samples have commercial value enable the salesmen to post a bond with the customs authorities in lieu of the payment of duties. Once the bond has been posted, the samples may be kept in the country for a period of six months. Under some of these treaties, traveling salesmen are permitted to sell their samples (subject, of course, to the payment of duties) without having to qualify as importers. Conventions to facilitate the work of traveling salesmen have been entered into between the United States and Colombia, ${ }^{51}$ Guatemala, ${ }^{52}$ Panama, ${ }^{53}$ Paraguay, ${ }^{54}$ Peru, ${ }^{55}$ El Salvador, ${ }^{56}$ Uruguay, ${ }^{57}$ and Venezuela."

With a number of other countries, provisions for the benefit of traveling salesmen are included in general commercial treaties. For instance in the Treaty of Friendship, Commerce and Consular rights with Estonia ${ }^{59}$ entered into in 1926 , it is provided in Article XIV that commercial travelers shall be accorded "the most favored nation treatment in respect to customs and other privileges and of all charges and taxes of whatever denomination applicable to them or to their samples." Similar "most favored nation" treatment is accorded to traveling salesmen by treaties with Honduras, ${ }^{60}$ Austria, ${ }^{61}$ Latvia, ${ }^{62}$ Norway, ${ }^{63}$ Poland, ${ }^{64}$ Finland, ${ }^{65}$ and Liberia. ${ }^{66}$ In the Commercial Treaty entered into with Hungary in $1926,{ }^{67}$ protection is afforded to traveling salesmen similar to that given in the conventions above referred to in the preceding paragraph.

While these treaties and conventions have not eliminated the problems which face traveling salesmen, they have at least gone a long way to reduce them and make those remaining less burdensome. The trend today by a number of countries is in favor of local representatives of American concerns which representatives would be responsible for all activities of traveling salesmen. In this way these countries seek

52 Treaty of Aug. 4, 1922, 3 Mallor, Treattes (1923) 254I (Sen. Doc. No. 348, 67th Cong., 4th Sess., being the third rolume of the series initially compiled by William M. Malloy).

E2 Treaty of Dec. 3, I9r8, id. at 2670 .

st Treaty of Oct. $20,1919, i d$. at 2791 .

"o Treaty of Jan. 28, rgig, id. at 2826 .

58 Treaty of July $3,1919, i d$. at 2867.

53 Treaty of Feb. 8, rg19, id. at 2780.

E5 Treaty of Jan. $19,1923, i d$. at 2800 .

57 Treaty of Aug. 27, 1919, id. at 2862.

${ }^{\circ}$ U. S. Treaty Series, No, 764, Dec. 7, 1927.

${ }^{6}$ U. S. Treaty Serics, No, 765, April 20, 1928.

-4 U. S. Treaty Series, No. 862, June I5, 1931 .

${ }^{\circ}$ U. S. Treaty Series, No. 956, Aug. 8, 1938.

${ }^{59}$ U. S. Treaty Series, No. 736 , Dec. $23,1925$.

${ }^{61} U$. S. Treaty Series, No. 838 , June $19,1928$.

${ }^{63}$ U. S. Treaty Series, No. 852, June 5, 1928.

${ }^{\circ}$ U. S. Treaty Series, No. 868, Feb. 13, 1934.

or U. S. Treaty Series, No. 748, June 24, 1925. 
a higher degree of accountability for the activities of the traveling salesmen. Panama does not permit operations through traveling salesmen, and requires that such operations be undertaken through locally established firms. ${ }^{08}$

Where sales are to be made to a public authority, a traveling salesman may find his authority too limited to carry through the sale. In some countries the seller is required to make a firm offer which may or may not be accepted by the public authority and this requires having a representative with full power to bind the seller in advance of acceptance. ${ }^{69}$

Subsidiary Corporations. We have discussed the procedure which an American corporation must follow if it desires to qualify to do business in a foreign country. Sometimes the American operating corporation does not wish to do so. This may be due to the policy of the American company, to the possible danger of lawsuits being brought against it in the foreign jurisdiction if it should qualify, or to the liability for taxes in the foreign jurisdiction. It may, therefore, decide to organize a subsidiary American corporation for the purpose and to qualify the latter in the foreign country. The provisions in the United States tax law relative to so-called Western Hemisphere Trade Corporations which are exempt from the corporate surtax and during the last war were also exempt from corporate excess profits tax, has led a number of concerns to form United States subsidiaries and to qualify them in the foreign country in which they plan to carry on their business. If it is proposed to do business in China the American subsidiary corporation must comply with the China Trade Act which requires the use of a District of Columbia corporation. The restrictions which may be encountered in qualifying these American subsidiary corporations are, of course, the same as those discussed in the case of American parent corporations. Recent developments in some countries have made the use of a United States subsidiary undesirable; for example, China now refuses to admit any foreign corporation which does not do business in the country of its origin, which would appear to exclude corporations organized under the China Trade Act.

Venezuela considers a foreign corporation which does business exclusively in Venezuela as a Venezuelan corporation with the consequences which we will describe at a later point.

The recent foreign exchange control and excess profits tax decrees in Brazil may make it difficult, if not impossible, for the American subsidiary to withdraw from Brazil the entire earnings from the Brazilian enterprise. At the same time the American subsidiary is subject to American corporate taxes even on earnings which cannot be withdrawn. This tax disadvantage, of course, would apply with like force to the parent company, if it should qualify in Brazil.

Perhaps the most popular method of doing business abroad today is through the formation of a business organization in the country where the enterprise is to

\footnotetext{
${ }^{63}$ Panama: Decree-Law No. 48 of Jan. II, I944: Gaceta Oficial No. 9298 of Jan. 12, 1944.

'El Salvador: Municipal Law of July 4, x908: Dinrio Oficial of Dec. 18, 1908, as amended.
} 
be carried on. This business organization may take the form of a limited liability company (a form of organization unknown in the United States but popular in many European and Latin-American countries), a limited partnership (rather similar to our own limited partnership), or a corporation. With respect to a foreign limited liability company or a foreign limited partnership, no particular limitations or restrictions will be encountered other than those which may be imposed on individual American citizens doing business in the foreign country. However, the limited liability company or the limited partnership concepts are not in general vogue with large companies. The most common method employed is the formation of a local corporation. Sometimes this local corporation is a wholly owned subsidiary. In recent years, however, the practice of associating local capital in the corporation has become more popular. We have seen that Mexico reserves the right to prescribe that at least $5^{1}$ percent ownership in such local corporations shall be in the hands of Mexicans. As a practical matter, however, this restriction has only been applied with respect to certain types of industries.

Colombia requires that at least $5 \mathrm{I}$ percent of the stock of local corporations engaged in the aviation business must be owned by Colombians. ${ }^{70}$

In Brazil an airship can be registered only if it belongs to a Brazilian citizen or corporation. ${ }^{\mathbf{7 1}}$

In Venezuela an airship can be registered if it belongs to a Venezuelan citizen, to a Venezuelan corporation or to any other corporation considered Venezuelan by law, to foreigners residing in Venezuela and in business or practicing a profession for over a year, or to foreign corporations which have been domiciled for more than one year. ${ }^{72}$

While there is no similar statutory provision in Peru, the government has required that a percentage of the stock in an aviation company shall be held by or at least offered to Peruvians.

The formation of a local corporation, of course, requires compliance with the local laws. Sometimes the American company thinks of the requirements of the local law as being restrictions on its ability to do business. This, of course, is not the case. By and large, it can be said that local corporations owned in whole or in part by foreigners are subject to the same requirements as those which are owned by nationals. In many cases these requirements differ from those in this country and it is these differences which are sometimes mistakenly looked upon as restrictions on foreign enterprise.

Argentina requires ten incorporators to organize a local corporation. ${ }^{\mathbf{7 3}}$ In Brazil the requirement is seven, but there the law provides that the corporation must continue at all times to have at least seven stockholders. ${ }^{74}$ If it falls under this re-

${ }^{70}$ Colombia: Law 89 of I938: Diario Oficial No. 23789 of May 30, I938.

${ }^{71}$ Brazil: Decree No. 20914 of Jan. 6, 1932: ColEção das LeIS DE I932, Vol. I, p. 9.

72 Venezuela: Law of July 13, I944: Gaceta Oficial, Extraordinario No. 87 of Julyn 13, r944.

73 Argentina: Code of Commerce, art. 318.

${ }^{74}$ Brazil: Decree-Law No. 2627, art. 36, of Oct. 26, I940: Coleção das LeIs de I940, Vol. V, p. 353. 
quirement and fails to make it up prior to its next annual meeting, it must go into dissolution. ${ }^{75}$

In Mexico five incorporators are necessary to form a local corporation and here again the law requires that there must continue to be at all times at least five stockholders. $^{76}$

These requirements on their face appear to present a problem for an American company which desires to carry on business through a wholly owned subsidiary in one of these countries. The problem, of course, can be met by having the minimum number of stockholders through the issuance of shares to local residents or to officers of the local corporation.

The laws or practice of most countries require that stockholders' meetings of local corporations be held in the country. These laws usually specify the books which the corporation shall maintain and a number of the Latin-American countries require the appointment by the stockholders of auditors, whose duties are to examine the books periodically, to approve financial statements and to report their findings to the stockholders. These auditors cannot be one of the regular officers or employees of the corporation and their main function is to protect the interests of the stockholders.

Usually the directors of a local corporation may be foreigners but directors' meetings, by and large, must be held in the country of incorporation. As a practical matter, therefore, it may be necessary to have local residents as directors. Mexico, which has perhaps gone further than any other country in this hemisphere in imposing restrictions on foreigners may require in some cases that a majority of the directors of the local corporation shall be Mexican. ${ }^{77}$ On the other hand, Panama permits the holding of stockholders' and directors' meetings outside of Panama and also permits directors to act through a proxy. Neither the directors nor any of the stockholders need be Panamanians or residents of Panama. ${ }^{78}$

Some Consequences of Registering a Foreign Corporation. Any American corporation qualifying to do business abroad must take into consideration or at least be informed of the practical results of obtaining a license and registering in the foreign country. As a general rule the first result is that the corporation is subject to all the laws of the country, particularly the laws affecting corporations. Such foreign corporations qualifying to do business abroad must also be aware of legislative provisions in the foreign country tending to equalize it to domestic corporations. Therefore, a foreign corporation registered abroad will usually be required to file all amendments to its charter and by-laws. In Cuba a foreign corporation is also required to file notice of any change in the authorized or issued capital and all changes in the Board of Directors. ${ }^{79}$

\footnotetext{
${ }^{75}$ Brazil: Decree-Law No. 2627, art. 137 (d), of Oct. 26, 1940, ibid.

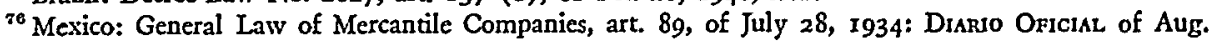

${ }_{77}$ Mexico: Decree of June 29, r944: Diario Ofictal of July 7, 1944.

${ }^{78}$ Panama: Corporation Law No. 32 of $x 927$.

${ }^{70}$ Cuba: Decree 1369 of May 16, I944: GACETA OFicisl of May 22, 1944, p. 8322, as amended by Decree 3444 of Oct. 5, r944: Gacets Oficial of Oct. I1, 1944, p. 16899.
} 4, 1934 . 
In Colombia a foreign corporation has been required to appoint an auditor as required for local corporations. ${ }^{30}$ It is true that such an auditor cannot protect the interests of the stockholders since he does not report to the American stockholders, but that auditor must approve any financial reports and balance sheets filed with the government. The laws of Mexico require that a foreign corporation qualifying to do business there for the purpose of acquiring land or water rights must specifically agree that the corporation shall for all intents and purposes be considered of Mexican nationality and to waive all right to protection by its government. ${ }^{81}$

In Venezuela ${ }^{82}$ corporations organized abroad having in Venezuela their principal seat of business are deemed national corporations, while those organized abroad having in Venezuela only a branch or operations which do not constitute their principal purpose, retain their nationality but shall be deemed domiciled in Venezuela. Foreign corporations which are deemed national corporations by law may register aeroplanes, which privilege is denied to other foreign corporations unless they have been domiciled in Venezuela at least a year.

In the Argentine ${ }^{83}$ corporations organized abroad to carry out in the Argentine their principal purpose, obtaining the major part of their capital in the Argentine, having therein their Board of Directors, and holding in the Argentine their stockholders' meetings, shall be deemed for all purposes national corporations subject to the provisions of the Argentine Code of Commerce.

While the general rule is to equalize these corporations to national corporations, the effort has not gone beyond compelling the foreign corporation to comply with the local requirements relating to the filing of amendments of the charter, the filing of reports, the payment of taxes, submission to inspection in those jurisdictions where there is a Superintendent or Inspector of Corporations, and other similar matters. We do not know of any instance in Latin America where a foreign corporation has been compelled to comply with the local requirements regarding the number of stockholders or the holding of meetings of directors or the other provisions of the local law relating to the legal structure of local corporations. In Colombia, for instance, a corporation cannot increase its capital without the approval of the Superintendent of Corporations. ${ }^{84}$ We do not know of any attempt to compel a foreign corporation qualified to do business in Colombia to obtain such authorization before it increases its capital, although the amendment adopted in the United States to carry out such increase must be registered in Colombia after the fact has been accomplished.

It would seem difficult to conceive how any such equalization could be carried to the extreme of compelling a foreign corporation to adjust itself to or to comply with each and every requirement of each country where it does business, particularly if these requirements are in conflict.

\footnotetext{
${ }^{80}$ Colombia: Revista de la Superintendencia de Sociedades Anónimas, Vol. I, No. I, p. 32.

${ }^{31}$ Mexico: Constitution of $x 9 x 7$, art. 27 and Law regulatory thereof.

${ }^{82}$ Venezuela: Code of Commerce, section 334.

${ }^{83}$ Argentina: Code of Commerce, art. 286 as amended by Law 3528 of Sept. 30, 1897.

* Colombia: Decree I570 of Aug. 13, I943: Diario Oficial No. 25327 of Aug. 21, 1943, p. 468.
} 


\section{Concluding Remarks}

We hope that the reader will gain the impression from this article that restrictions and limitations as such on property acquisition and enterprise in foreign countries are not common in countries which continue to recognize and encourage the carrying on of private enterprise. The greatest danger which can presently be foreseen is that many countries through their nationalization programs will so transform their economies as to preclude the carrying on of enterprise by foreigners. In those countries where today American businessmen may trade or acquire property or engage in local commercial activity, the problems being encountered are due not so much to restrictions directed against foreign enterprise and property acquisition, as to general fiscal policies. All of these countries have tariff laws just as we do, which in some cases act as a deterrent to the import of American merchandise. Some have import controls. The exchange control laws now in force in many of them have proved a deterrent to our trade. The tax laws of the country may also affect the ability of foreigners to trade or do business. This is particularly true where the tax law, such as the recent excess profits tax in Brazil levied not only for revenue but as an inflationary curb, may freeze in the country a substantial part of the earnings of the foreign enterprise. It is of the utmost importance that any student of foreign trade restrictions carefully consider these aspects of the problem, which are beyond the scope of this article. 